Canadian University Music Review

Revue de musique des universités canadiennes

\title{
Konstanze Musketa. Musikgeschichte der Stadt Halle. Führer durch die Ausstellung des Händel-Hauses. Halle an der Saale: Händel-Haus, 1998. 113 pp. ISBN 3-910019-13-7 (paperback)
}

\section{Barbara Reul}

Volume 22, numéro 2, 2002

URI : https://id.erudit.org/iderudit/1014513ar

DOI : https://doi.org/10.7202/1014513ar

Aller au sommaire du numéro

Éditeur(s)

Canadian University Music Society / Société de musique des universités canadiennes

ISSN

0710-0353 (imprimé)

2291-2436 (numérique)

Découvrir la revue

Citer ce compte rendu

Reul, B. (2002). Compte rendu de [Konstanze Musketa. Musikgeschichte der Stadt Halle. Führer durch die Ausstellung des Händel-Hauses. Halle an der Saale: Händel-Haus, 1998. 113 pp. ISBN 3-910019-13-7 (paperback)]. Canadian

University Music Review / Revue de musique des universités canadiennes, 22(2), 140-142. https://doi.org/10.7202/1014513ar

All Rights Reserved (c Canadian University Music Society / Société de musique des universités canadiennes, 2003
Ce document est protégé par la loi sur le droit d'auteur. L’utilisation des services d'Érudit (y compris la reproduction) est assujettie à sa politique d'utilisation que vous pouvez consulter en ligne.

https://apropos.erudit.org/fr/usagers/politique-dutilisation/ 
Konstanze Musketa. Musikgeschichte der Stadt Halle. Führer durch die Ausstellung des Händel-Hauses. Halle an der Saale: Händel-Haus, 1998. 113 pp. ISBN 3-910019-13-7 (paperback).

What do composers Samuel Scheidt, David Pohle, Friedrich Wilhelm Zachow, George Frederic Handel, Wilhelm Friedemann Bach, Daniel Gottlob Türk, Johann Friedrich Reichardt, Carl Loewe and Robert Franz have in common? Correct answers probably range from "they were all German" to "the above composers influenced the development of either keyboard or choral literature or excelled in writing Lieder." Those readers, however, who responded that these individuals were either born or active in or near the city of Halle an der Saale would have scored the highest. Despite its impressive, extremely rich and culturally diverse musical life ever since the Middle Ages, Halle has never been able to step out of the shadow of Leipzig, less than forty kilometers east of Halle. The city's most famous musical claim to fame is undoubtedly George Frederic Handel who was born in Halle in 1685 and advanced to become the most important English composer of the early eighteenth century. Like Bach in Leipzig and Mozart in Salzburg, Handel reigns in downtown Halle: in addition to a large Handel monument right in the middle of the downtown market square, the agenda of every VIP and musically-inclined tourist includes a visit to the Händel-Haus Halle, an internationally renowned music museum dedicated primarily to the life and works of Handel. Moreover, an ever-growing number of Baroque music aficionados attend numerous concerts offered over the course of ten days in June of every year as part of Halle's Internationale HändelFestspiele. ${ }^{1}$

In 1989 the Händel-Haus Halle mounted a permanent exhibition on the musical history of the city of Halle, entitled Musikgeschichte der Stadt Halle. An accompanying booklet was prepared by Konstanze Musketa, in 1998. ${ }^{2}$ Musketa's guide fills an obvious lacuna with regard to publications on the musical history of Halle. Prior to this well-thought out publication interested readers could choose only from books that were either too complex or too general in nature (p. 112). ${ }^{3}$ Musketa's guide-113 pages of well-laid out text, a number of illustrations, a supplementary reading list, and a handy "you-arehere-map" for each "room"- -meets the needs and expectations of both music amateurs and professionals. By documenting a carefully selected number of

1 For information, see www.haendelfestspiele.halle.de or www.halle.de.

2Rooms 1 and 2 had been designed on the occasion of a scholarly conference dedicated to Samuel Scheidt in 1987. Rooms 3 to 8 were presented to the public in 1989. Room 7 was redone in the mid-1990s, Room 8 and Room 6 in 1998 and in 1999, respectively. Personal communication from Dr. Musketa to the author, 12 June 2000.

3 Musicologists tend to prefer Walter Serauky's detailed musical history of the city of Halle; see his Musikgeschichte der Stadt Halle, 2 volumes (Halle/Saale, Berlin: Buchhandlung des Waisenhauses); vol. I, "Von den Anfängen bis zum Beginn des 17. Jahrhunderts," 1935; vol. 2, part 1: "Von Samuel Scheidt bis in die Zeit Georg Friedrich Händels und Johann Sebastian Bachs," 1939, vol. 2, part 2: "Von Wilhelm Friedemann Bach bis Robert Franz," 1942. Only two other publications of a general nature are mentioned in Musketa's list of recommended reading. Halle als Musikstadt from 1954 is likely to be not readily available at libraries in North America, and Halle an der Saale: kleine Musikgeschichte published by the Halle Tourist Information in 1984, was obviously geared toward travelers. 
significant events, composers, and individuals, she successfully emphasizes Halle's importance in music history.

My first thought when skimming through this guidebook was that if this publication were in English, it would make a great basic textbook for a third-year music history course. One only has to convert the "Rooms 1 through 8 " into book chapters (no table of contents can be found) to create an excellent survey of roughly 500 years worth of music history as experienced by citizens of Halle. "Raum 1: Mittelalter und Renaissancezeit" covers the Middle Ages and the Renaissance, Samuel Scheidt and his achievements as a composer and influence on the development of musical style are discussed in "Raum 2," while Barocke Musikpflege (Musical performances in the Baroque Era, ${ }^{4}$ including fewer than two pages on G. F. Handel) ${ }^{5}$ kindle our interest in "Raum 3." Specific composers Wilhelm Friedemann Bach, Daniel Gottlob Türk und Johann Friedrich Reichardt require undivided attention in "Raum 4" and "Raum 5," respectively. In "Raum 6" Musketa examines musical life in Halle during the nineteenth and the first half of the twentieth century. Information on Musikleben nach dem zweiten Weltkrieg bis zur Wiedervereinigung Deutschlands (Musical life in Halle after World War II until the reunification of Germany [1945-1990]) is provided in "Raum 7," and finally, in "Raum 8," readers will increase their knowledge about Hallesche Musikpflege nach der Wiedervereinigung Deutschlands-die Neunziger Jahre (Musical life in Halle after Germany's reunification during the 1990s).

The text for each "Raum" or chapter is divided into several subchapters, with subheadings and marginal notations facilitating easy reading. High-quality reproductions of primary sources-in black and white as well as in colourcomplement the publications' high visual impact and accentuate the great number of unique exhibition pieces. They range from rare manuscripts and autographs to priceless instruments which the Händel-Haus was able to acquire for its collection since 1937. In addition, photographs of each exhibition room recall the actual display of the exhibition pieces, and help recreate the special ambience of each musical-historical period. It is, however, Musketa's accompanying text that brings to life most vividly the many events that have so greatly influenced Halle's musical history. She effortlessly amalgamates a great number of essential, important and noteworthy pieces of information into a cleverly designed and logically presented publication of special interest. Readers will also appreciate her approach to the topics at hand from a larger cultural-historical perspective. With regard to literature, she notes, in particular, the continued presence of poets Brentano, Novalis, Eichendorff, and Goethe, all of whom had studied in Halle (Giebichensteiner Poetenparadies, p. 48). Musketa also stresses

4Unless otherwise noted, all translations in this review are mine.

5 This less than adequate amount of space reserved for the city's most famous musical prodigy must be understood in a larger context. The exhibition on Halle's musical history is shown inside the Händel-Haus which promotes the life and works of Handel in a museum setting. Nearly half a million individuals have visited the Händel-Haus since 1987, with at least 4,000 visitors enjoying the specialized exhibition documented in the above guidebook. I would like to thank Dr. Musketa for providing me with these statistics. 
the development of Händelpflege in Halle, that is the continuous, successful promotion of Handel's life and works since the turn of the nineteenth century.

Whereas the information presented in Chapters 1 through 6 can more or less easily be located in musicological textbooks, the last two chapters of the guide cover musical life in Halle from 1945 to 1998 , a part of musical history with which very few readers will be familiar. Musketa calls Chapter 7 "A new beginning" and reports on the activities of choirs, choruses, and orchestras as well as the opera house and musical theatre after World War II. Konfrontation mit neuer Musik (Confrontation with new music) draws our attention to "courageous composers such as Hans Jürgen Wenzel and Gerd Domhardt" (p. 94). They employed a new musical language as early as the 1970s which followed international instead of strict "socialist-realist" trends as dictated by the German Democratic Republic. With regard to music education in public schools, its communist government had interfered as early as 1951, converting Halle's famous Stadtsingechor into a boys' choir of the state of Saxony-Anhalt when its director Alfred Zimmer had stressed the Stadtsingechor's traditional participation in religious services. Nevertheless, church music continued to play an important role in Halle's musical-cultural life-many excellent organists and choirs offered concerts on a regular basis, performing works by composers connected with Halle, especially Handel, Bach, and Scheidt.

Germany's reunification in 1990 resulted in a great number of fortuitous changes in the city's musical life. Important musical performance venues, among them the 300-year-old Franckesche Stiftungen, were restored and are now regularly used by Halle's numerous orchestras and choirs, including high school students from the local Landesgymnasium (University Preparatory School) August Hermann Francke. Many of its students become members of the Martin Luther University of Halle-Wittenberg's Collegium musicum and the Johann Friedrich Reichardt University Chorus which regularly perform in and outside of Halle. Others take a degree in church music at Halle's local Hochschule for Lutheran Church Music, while students interested in different musical styles join the University's Department of Education Big Band.

Musketa's discussion of the promotion of Handel's music at the close of the second millennium brings us full circle. The annual Internationale HändelFestspiele, the many activities at the Halle Opera House and in other concert venues underscore the city's healthy cultural life. Musketa-and hence the exhibition-closes with Musik auf Strassen und Plätzen (Outdoor music). This reminds us that without "popular" music in Halle (rock, pop, jazz, and music played in local cafés and pubs), an account of Halle's musical history would be incomplete.

I would like to encourage readers with even limited knowledge of German to try their hand at this wonderful publication-music librarians, take note as well. Musketa's German is comparatively easy to comprehend; there are only a few complex sentences with which to struggle. Those who are currently planning a trip to Germany are urged to include Halle and especially the Händel-Haus in their travel plans. The city is only a short distance from Leipzig, and-as I hope I have argued here-well worth your effort.

Barbara M. Reul 